\title{
Control of Microorganisms In Vitro by Endodontic Irrigants
}

\author{
Cyntia R.A. ESTRELA ${ }^{1}$ \\ Carlos ESTRELA ${ }^{1}$ \\ Cleômenes REIS ${ }^{1}$ \\ Lili Luschke BAMMANN² \\ Jesus Djalma PÉCORA ${ }^{3}$ \\ ${ }^{1}$ Faculty of Dentistry, Federal University of Goiás, Goiânia, GO, Brazil \\ ${ }^{2}$ Faculty of Dentistry, Lutheran University of Brazil, Porto Alegre, RS, Brazil \\ ${ }^{3}$ Faculty of Dentistry of Ribeirão Preto, University of São Paulo, Ribeirão Preto, SP, Brazil
}

\begin{abstract}
The aim of this study was to determine the minimum inhibitory concentration (MIC) and antimicrobial effectiveness by the direct exposure test of 4 endodontic irrigants $\left[1 \%\right.$ sodium hypochlorite $(\mathrm{NaOCl}), 2 \%$ chlorhexidine $(\mathrm{CHX}), 1 \%$ calcium hydroxide $\left(\mathrm{Ca}(\mathrm{OH})_{2}\right.$; prepared with $1 \mathrm{~g}$ of $\mathrm{Ca}(\mathrm{OH})_{2}$ and $100 \mathrm{~mL}$ of sterile distilled water), a solution of $\mathrm{Ca}(\mathrm{OH})_{2}+$ detergent $\left.(\mathrm{HCT} 20)\right]$ for $S$. aureus, E. faecalis, $P$. aeruginosa, B. subtilis, C. albicans and a mixed culture. Microbial growth was analyzed by two methods: turbidity of the culture medium that was confirmed by Gram stain and subculture in a specific nutrient broth. In the dilution test, $\mathrm{NaOCl}$ solution showed MIC equal to $0.1 \%$ for $S$. aureus, E. faecalis, $P$. aeruginosa and $C$. albicans and equal to $1 \%$ for $B$. subtilis and the mixed culture. CHX (2\%) presented MIC equal to $0.000002 \%$ for $S$. aureus, $0.02 \%$ for E. faecalis, B. subtilis, C. albicans and the mixed culture and $0.002 \%$ for $P$. aeruginosa. $\mathrm{Ca}(\mathrm{OH})_{2}$ solution $(1 \%)$ showed MIC greater than $1 \%$ for all the microorganisms except $P$. aeruginosa for which it was equal to $1 \%$. Calcium hydroxide solution + detergent showed MIC equal to $4.5 \mathrm{~mL}$ for $S$. aureus, $P$. aeruginosa, B. subtilis, C. albicans and the mixed culture and greater than $4.5 \mathrm{~mL}$ for E. faecalis. In the direct exposure test, $\mathrm{NaOCl}$ had better antimicrobial effectiveness for all microorganisms at all times. CHX (2\%) was effective for S. aureus, E. faecalis and C. albicans at all times, and ineffective for $P$. aeruginosa, B. subtilis and the mixed culture. The other solutions showed the worst results.
\end{abstract}

Key Words: endodontic irrigants, sodium hypochlorite, chlorhexidine digluconate, intracanal dressing.

\section{INTRODUCTION}

The process observed between endodontic infection and consequential host response has led to several therapeutic trends. The sanitization process of an infected root canal is the objective of endodontic therapy. Chemical and mechanical cleaning and shaping significantly reduce the number of microorganisms, but do not eliminate them (1).

Although, various irrigants have been indicated for the sanitization process in apical periodontitis and many of them have shown varied degrees of antimicrobial effectiveness (1-5), the choice of the ideal irrigant solution and its concentration is difficult. In a clinical study, Byström and Sundqvist (6) showed no antibacterial difference between $0.5 \%$ and $5 \% \mathrm{NaOCl}$ solutions.
Heling and Chandler (7) analyzed the antimicrobial effect of irrigant combinations within dentinal tubules and concluded that $0.12 \% \mathrm{CHX}$ and $1 \% \mathrm{NaOCl}$ were similarly effective. Ohara et al. (2) compared six irrigants on selected anaerobic bacteria. $0.2 \% \mathrm{CHX}$ was the most effective; $3 \%$ hydrogen peroxide, $5.25 \% \mathrm{NaOCl}$ and $17 \%$ REDTA were less effective while the saturated solution of $\mathrm{Ca}(\mathrm{OH})_{2}$ and saline proved to be totally ineffective. Ayhan et al. (4) reported the antimicrobial effects of various endodontic irrigants on selected microorganisms and observed that $5.25 \% \mathrm{NaOCl}$ was superior and the reduced concentration of $0.5 \%$ resulted in significantly decreased antimicrobial effectiveness.

Considering the different research results, an important factor to analyze is the MIC of endodontic 
irrigant solutions capable of controlling microorganisms and, then, to compare antimicrobial effectiveness. Thus, the purpose of this study was to compare in vitro the antimicrobial effectiveness of $1 \% \mathrm{NaOCl}, 2 \% \mathrm{CHX}$, $1 \% \mathrm{Ca}(\mathrm{OH})_{2}$ solution and $\mathrm{Ca}(\mathrm{OH})_{2}$ solution with a detergent and determine their MIC using Staphylococcus aureus, Enterococcus faecalis, Pseudomonas aeruginosa, Bacillus subtilis, Candida albicans and a mixed culture of these microorganisms as biological indicators.

\section{MATERIAL AND METHODS}

\section{Test Organisms}

Four reference bacterial strains - Staphylococcus aureus (ATCC 6538), Enterococcus faecalis (ATCC 29212), Pseudomonas aeruginosa (ATCC 27853), and Bacillus subtilis (ATCC 6633), obtained from the American Type Culture Collection, and one strain of yeast Candida albicans (ICB/USP - 562), isolated at

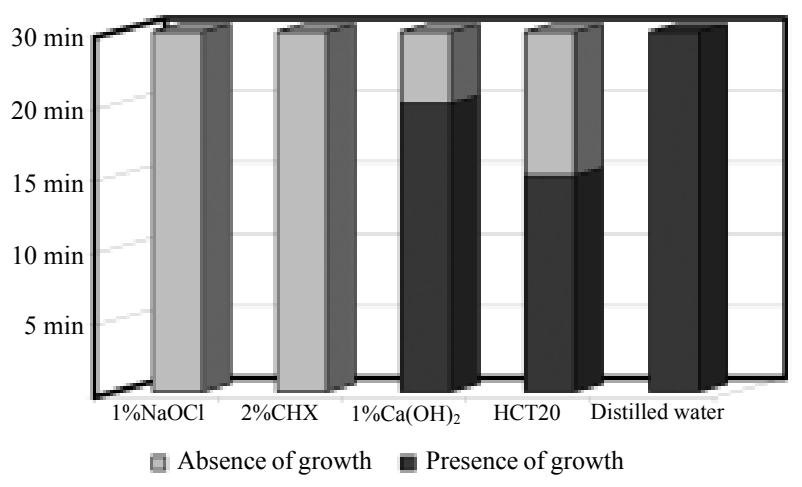

Figure 1. Antimicrobial effect of irrigant solutions for S. aureus.

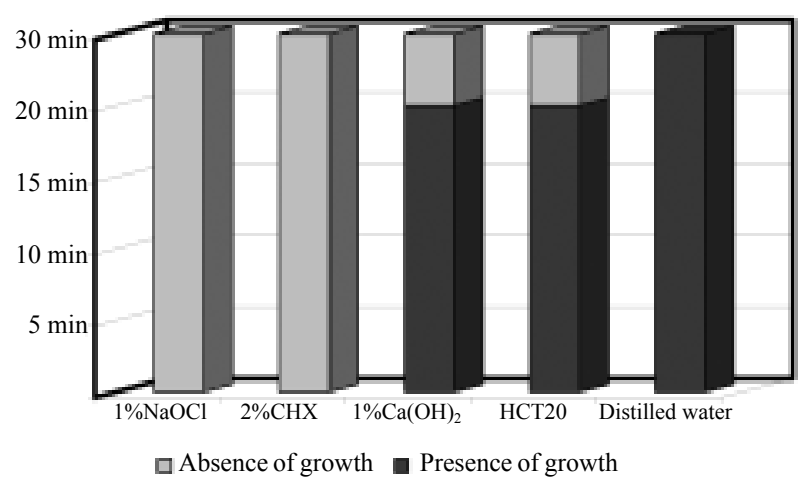

Figure 2. Antimicrobial effect of irrigant solutions for E. faecalis. the Laboratory of Biological Science, University of São Paulo, Brazil, were included in this study.

The strains were inoculated in $7 \mathrm{~mL}$ of brain heart infusion (BHI; Difco Laboratories, Detroit, MI, USA) and incubated at $37^{\circ} \mathrm{C}$ for $24 \mathrm{~h}$. To prepare the experimental suspensions, the biological indicators were cultivated on brain heart infusion agar (BHIA; Difco Laboratories), following the same incubation conditions. Microbial cells were resuspended in saline to give a final concentration of about $3 \times 10^{8}$ cells $/ \mathrm{mL}$, similar to that of tube No. 1 of the MacFarland scale. One $\mathrm{mL}$ of each of these pure suspensions was used to obtain a mixture of the test microorganisms.

\section{Determining Minimum Inhibitory Concentration}

The following irrigant solutions were used: $1 \%$ $\mathrm{NaOCl}$ (Halex Istar, Goiânia, GO, Brazil); 2\% chlorhexidine digluconate (F.G.M., Joinville, SC, Brazil); $1 \% \mathrm{Ca}(\mathrm{OH})_{2}$ solution (prepared with $1 \mathrm{~g}$ of calcium hydroxide (Quimis, Maillinkoet Inc., St. Louis, MO, USA) and $100 \mathrm{~mL}$ of sterile distilled water); a solution of $\mathrm{Ca}(\mathrm{OH})_{2}+$ detergent - lauryl diethyleneglycol ether sodium sulfate (Tergentol; Searle of Brazil, Rio de Janeiro, RJ, Brazil) ( $80 \mathrm{~mL}$ of $0.2 \%$ calcium hydroxide solution $+20 \mathrm{~mL}$ of Tergentol).

To determine the MIC of the irrigant solutions, ten-fold dilutions were made in $4.5 \mathrm{~mL}$ of BHI. After the dilution of the irrigant solutions, an inoculum of 0.1 $\mathrm{mL}$ obtained from the experimental suspensions was added, followed by incubation at $37^{\circ} \mathrm{C}$ for $48 \mathrm{~h}$. Microbial growth was analyzed by two methods - turbidity of the culture medium and subculture in an specific nutrient broth - because some of the tested irrigants caused

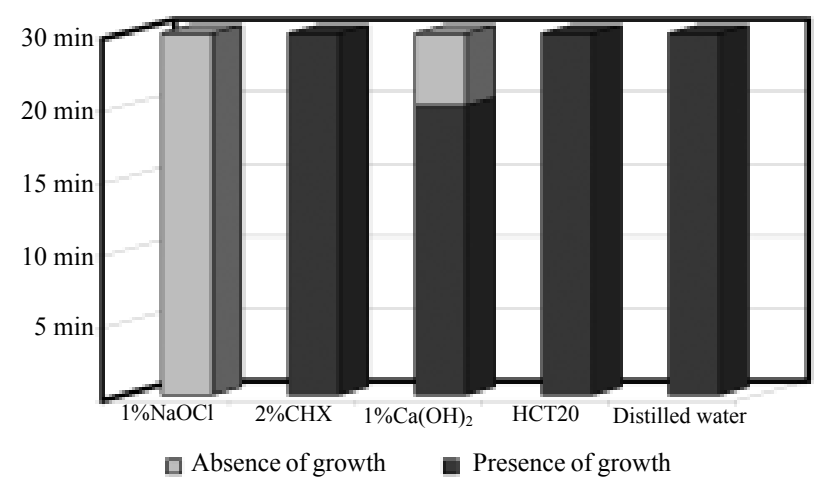

Figure 3. Antimicrobial effect of irrigant solutions for $P$. aeruginosa. 
culture medium changes. In this particular method, an inoculum of $0.1 \mathrm{~mL}$ obtained from the BHI + irrigant + microorganisms was transferred to $7 \mathrm{~mL}$ of Letheen broth (LB; Difco Laboratories, Detroit, MI, USA), a medium containing or added with neutralizers: lecithin, Tween 80 and sodium thiosulfate (Art Laboratories, Campinas, SP, Brazil) in appropriate concentrations, and subsequently incubated under adequate atmosphere. After $48 \mathrm{~h}, 0.1 \mathrm{~mL}$ of these culture was transferred to 7 $\mathrm{mL}$ of BHI followed by identical incubation conditions. Finally, microbial growth was macroscopically evaluated by culture medium turbidity and when necessary microscopically confirmed by Gram stain. All assays were carried out in duplicate under aseptic techniques.

\section{Testing Antimicrobial Action after Different Exposure Times}

Three hundred and sixty size 50 sterile absorbent paper points (Tanari, Tanariman Indústria, Ltda., Manacaru, AM, Brazil) were immersed in the experi-

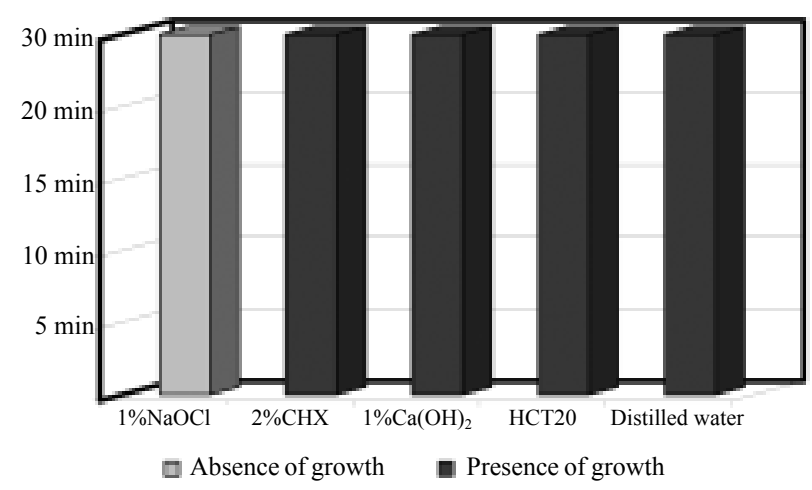

Figure 4. Antimicrobial effect of irrigant solutions for B. subtilis.

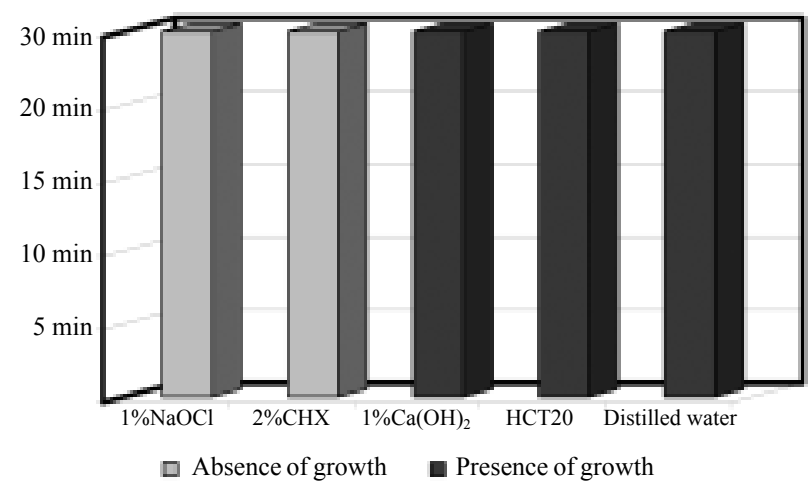

Figure 5. Antimicrobial effect of irrigant solutions for C. albicans. mental microbial suspension for 5 min. The paper points were then placed on Petri dishes and covered with $10 \mathrm{~mL}$ of the irrigant solutions. Two controls were used for testing LB sterility and for checking microorganism viability throughout the experiment.

At intervals of 5, 10, 15, 20 and $30 \mathrm{~min}, 72$ absorbent paper points were removed from contact with the irrigant solutions and individually transported and immersed in $7 \mathrm{~mL}$ of LB followed by incubation at $37^{\circ} \mathrm{C}$ for $48 \mathrm{~h}$. Microbial growth was evaluated by the previously described methods. After evaluating LB changes, an inoculum of $0.1 \mathrm{~mL}$ was obtained from medium and transferred to $7 \mathrm{~mL}$ of BHI, and incubated under identical conditions. Microbial growth was verified by turbidity of the culture medium and in some cases by Gram stain. All assays were carried out in duplicate under aseptic conditions.

\section{RESULTS}

In the dilution test, $\mathrm{NaOCl}$ solution showed MIC equal to $0.1 \%$ for $S$. aureus, E. faecalis, $P$. aeruginosa and $C$. albicans and equal to $1 \%$ for $B$. subtilis and the mixed culture. CHX (2\%) presented MIC equal to $0.000002 \%$ for $S$. aureus, $0.02 \%$ for E. faecalis, $B$. subtilis, $C$. albicans and the mixed culture and $0.002 \%$ for $P$. aeruginosa. $\mathrm{Ca}(\mathrm{OH})_{2}$ solution $(1 \%)$ showed MIC greater than $1 \%$ for all the microorganisms except $P$. aeruginosa for which it was equal to $1 \%$. $\mathrm{Ca}(\mathrm{OH})_{2}$ solution + detergent showed MIC equal to $4.5 \mathrm{~mL}$ for $S$. aureus, $P$. aeruginosa, B. subtilis, C. albicans and the mixed culture and greater than $4.5 \mathrm{~mL}$ for $E$. faecalis.

Using the direct exposure test, $\mathrm{NaOCl}$ had the best antimicrobial effectiveness for all microorganisms

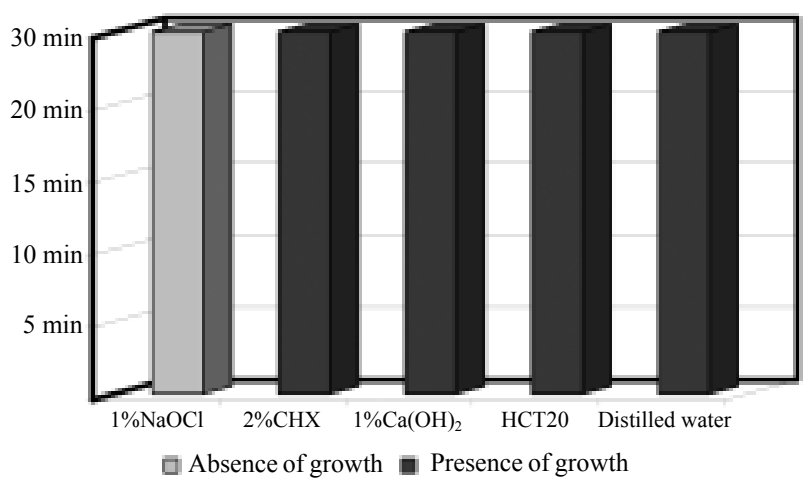

Figure 6. Antimicrobial effect of irrigant solutions for the mixed culture of microorganisms. 
at all times. CHX was effective for S. aureus, E. faecalis and $C$. albicans at all times, and ineffective for $P$. aeruginosa, B. subtilis and the mixed culture of the microorganisms. The irrigant solutions containing calcium hydroxide showed the worst results. The results are shown in Figures 1-6.

\section{DISCUSSION}

Various results have been reported for irrigant antimicrobial effectiveness. Similar results have been reported for $\mathrm{NaOCl}$ and $\mathrm{CHX}(5,7-8)$; however, other research has shown that $\mathrm{NaOCl}$ has better antimicrobial activity than CHX (4, 9-10), or, conversely, that CHX has better antimicrobial activity than $\mathrm{NaOCl}$ (2-3). These differences may have been caused by different experimental methods, concentration, type of irrigant solution, or the period of analysis.

Estrela et al. (11) discussed that the physicochemical characteristics of $\mathrm{NaOCl}$ are essential for the explanation of its mechanism of action. Saponification, neutralization of amino acids and chloramination reactions that occur in the presence of microorganisms and organic tissue aid the antimicrobial and tissue dissolution processes. Antimicrobial activity is related to bacterial essential enzymatic sites promoting irreversible inactivation by hydroxyl ions and chloramination reaction. Sodium hypochlorite promotes biosynthetic alterations in cell metabolism, phospholipid destruction, and formation of chloramines that interfere in cell metabolism and oxidant action. The organic dissolution action can be observed in the saponification reaction when sodium hypochlorite destroys lipids and fatty acids resulting in soap and glycerol.

The MIC of $1 \% \mathrm{NaOCl}$ was $0.1 \%$ for S. aureus, E. faecalis, $P$. aeruginosa and C. albicans and $1 \%$ for $B$. subtilis and the mixed culture. Thus, the use of the lower concentration, $1 \% \mathrm{NaOCl}$ solution, can be recommended because of its antimicrobial activity, pulp tissue dissolution and acceptable tissue cytotoxicity. At higher concentrations, $\mathrm{NaOCl}$ is more aggressive while at lower concentrations $(0.5 \%$ to $1 \%)$, it is biocompatible $(12,13)$. For a substance to meet acceptable parameters of biocompatibility it must present only a discrete tissue reaction or none at all time periods and moderate or intense tissue reaction at 7 days that decreases in intensity with time, reaching a non-significant tissue reaction at 60 days (14). Other properties must also be considered when choosing an irrigant solution, i.e., $\mathrm{NaOCl}$ provides expressive tissue solvent action.

It is important to emphasize that the experimental methods, biological indicators and exposure time can influence the magnitude of the antimicrobial effect of irrigant solutions (15). Estrela et al. (15) verified the antimicrobial action of $2 \% \mathrm{NaOCl}$ and $\mathrm{CHX}$ by two different methods. The best performance of antimicrobial effectiveness of $\mathrm{NaOCl}$ was observed with the direct exposure test, and of CHX with the agar diffusion test.

The solvent effect of $0.1 \%, 1.0 \%, 2.5 \%$ and $5.0 \% \mathrm{NaOCl}$ solutions on bovine pulp tissue, the level of residual chlorine, $\mathrm{pH}$ and surface tension before and after tissue dissolution were studied in vitro by Spanó et al. (16). Their results showed that all concentrations of $\mathrm{NaOCl}$ reduced the $\mathrm{pH}$ and the surface tension, and the higher concentrations had the least consumption of chlorine during tissue dissolution. The residual chlorine was directly proportional to the concentration in the process of pulp tissue dissolution and there was residual chlorine at all concentrations used in this study.

Other research has concluded that CHX presents antimicrobial action $(2,3,5,15,17)$. In the present study, S. aureus, E. faecalis and C. albicans showed greater sensitivity to CHX. The MIC of CHX for $S$. aureus was $0.000002 \%$. Emilson (17) observed lower MIC for Staphylococcus sp., S. mutans and S. salivarius. Silva (3) determined, in vivo, the antimicrobial effectiveness of $1 \% \mathrm{NaOCl}$ and $2 \% \mathrm{CHX}$ as endodontic irrigants. Using $1 \% \mathrm{NaOCl}$ as irrigant, $16.7 \%$ and $83.3 \%$ of the canals were positive in the microbiological test, immediately and 7 days after therapy, respectively. Using $2 \%$ CHX, the percentages of positive cultures were $8.3 \%$ and $41.7 \%$, respectively, taking into account the immediate and residual effects. This indicates that both irrigants possess a similar effect immediately after biochemical treatment; however, irrigation with $2 \%$ chlorhexidine was more effective than $1 \% \mathrm{NaOCl}$ after 7 days. Gomes et al. (5) investigated, in vitro, antimicrobial activity of several concentrations of $\mathrm{NaOCl}$ and CHX in the elimination of E. faecalis. CHX (1\% and $2 \%$ ) and $5.25 \% \mathrm{NaOCl}$ required significantly less time to eliminate $E$. faecalis.

The inhibitory effect of CHX on the proteolytic activity may have an additional effect that contributes to the arrest of caries. There is ample evidence that $\mathrm{CHX}$ is a potent antimicrobial agent with high specific- 
ity against cariogenic bacteria, i.e. S. mutans (18).

Buck et al. (19) analyzed the detoxification of endotoxin by endodontic irrigants (CHX, $\mathrm{NaOCl}, \mathrm{CHX}$ chloride, ethanol, EDTA, water) and $\mathrm{Ca}(\mathrm{OH})_{2}$ and reported that the biologically active portion of endotoxin, lipid A, is hydrolyzed by highly alkaline chemicals, namely $\mathrm{Ca}(\mathrm{OH})_{2}$ or a mixture of $\mathrm{CHX}$, sodium hypochlorite and ethanol. EDTA, $\mathrm{NaOCl}, \mathrm{CHX}, \mathrm{CHX}$ chloride, ethanol and water (control) showed little or no detoxifying ability for lipid A.

Antimicrobial action by calcium hydroxide is determined by the liberation of hydroxyl ions, which requires an ideal length of time for effective microbial destruction. The liberation of hydroxyl ions to attain the high $\mathrm{pH}$ that may completely eliminate the microorganisms can be delayed. However, the irrigant solutions containing $\mathrm{Ca}(\mathrm{OH})_{2}$ compared with other solutions tested did not show significant effectiveness at the periods studied in this experiment.

Using a different experimental method, Barbosa et al. (20) evaluated the antimicrobial efficacy of calcium hydroxide solutions, pure and with detergent added, on various microorganisms. The saturated calcium hydroxide solution was effective against only four of the 11 microorganisms studied over a 60-min exposure time. The calcium hydroxide containing detergent killed all 11 test organisms over a 30-min exposure time.

When choosing an irrigant solution, a combination of various properties, such as antimicrobial action, pulp tissue dissolution, and acceptable biologic compatibility, should be considered. $\mathrm{NaOCl}$ in less concentrated solutions $(1.0 \%)$ provides these important properties. Further research is required to verify the antimicrobial efficiency of irrigant solutions in infected root canals with apical periodontitis.

\section{RESUMO}

O objetivo deste estudo foi determinar a concentração inibitória mínima (MIC) e o efeito antimicrobiano, através do teste de exposição direta, de quatro soluções irrigantes [hipoclorito de sódio a $1 \%$, clorexidina a $2 \%$, solução de hidróxido de cálcio a $1 \%$ - preparada com $1 \mathrm{~g}$ de $\mathrm{Ca}(\mathrm{OH})_{2}$ e $100 \mathrm{~mL}$ de água destilada esterilizada, solução de hidróxido de cálcio + detergente (HCT20)] sobre $S$. aureus, E. faecalis, P. aeruginosa, B. subtilis, $C$. albicans e uma cultura mista. $\mathrm{O}$ crescimento microbiano foi analisado por dois métodos: turvação do meio de cultura e confirmação pela coloração de Gram e subcultura em caldo nutriente específico. No teste de diluição, o hipoclorito de sódio a $1 \%$ apresentou MIC igual a $0,1 \%$ para $S$. aureus, E. faecalis, $P$. aeruginosa, e $C$. albicans e igual a $1 \%$ para o $B$. subtilis e a cultura mista. A clorexidina a $2 \%$ mostrou MIC igual a $0,000002 \%$ para o $S$. aureus, $0,02 \%$ para $E$. faecalis, B. subtilis, C. albicans e a cultura mista e $0,002 \%$ para $P$. aeruginosa. A solução de hidróxido de cálcio a $1 \%$ apresentou MIC superior a $1 \%$ para todos os microrganismos testados, com exceção da P. aeruginosa, cuja MIC foi igual a $1 \%$. A solução de hidróxido de cálcio + detergente mostrou MIC igual a $4,5 \mathrm{~mL}$ para $S$. aureus, $P$. aeruginosa, $B$. subtilis, $C$. albicans e a cultura mista e superior a 4,5 mL para o E. faecalis. No teste de exposição direta, o hipoclorito de sódio a $1 \%$ apresentou melhor efeito antimicrobiano para todos os microrganismos em todos os períodos experimentais. A clorexidina a $2 \%$ foi efetiva sobre $S$. aureus, E. faecalis, e $C$. albicans em todos os períodos, e inefetivo sobre $P$. aeruginosa, B. subtilis e sobre a cultura mista. As outras soluções mostraram os piores resultados.

\section{REFERENCES}

1. Byström A, Sundqvist G. Bacteriologic evaluation of the efficacy of mechanical root canal instrumentation in endodontic therapy. Scand J Dent Res 1981;89:321-328.

2. Ohara PK, Torabinejad M, Kettering JD. Antibacterial effect of various endodontic irrigants on selected anaerobic bacteria. Endod Dent Traumatol 1993;9:95-100.

3. Silva CAG. Efetividade antimicrobiana do hipoclorito de sódio e clorexidina como irrigantes endodônticos. [Master's thesis]. Porto Alegre: Universidade Luterana de Brasil, 1999.

4. Ayhan H, Sultan N, Cirak M, Ruhi MZ, Bodur H. Antimicrobial effects of various endodontic irrigants on selected microorganisms. Int Endod J 1999;32:99-102.

5. Gomes BPFA, Ferraz CCR, Vianna ME, Berber VB, Teixeira FB, Souza-Filho FJ. In vitro antimicrobial activity of several concentrations of sodium hypochlorite and chlorhexidine gluconate in the elimination of Enterococcus faecalis. Int Endod J 2001;34: 424-428.

6. Byström A, Sundqvist G. The antibacterial action of sodium hypochlorite and EDTA in 60 cases of endodontic therapy. Int Endod J 1985;18:35-40.

7. Heling I, Chandler NP. Antimicrobial effect of irrigant combinations within dentinal tubules. Int Endod J 1998;31:8-14.

8. Jeansonne MJ, White RR. A comparison of $2 \%$ chlorhexidine gluconate and $5.25 \%$ sodium hypochlorite as antimicrobial endodontic irrigant. J Endod 1994;20:276-278.

9. Ringel AM, Patterson SS, Newton CW, Miller CH, Mulhern JM. In vivo evaluation of chlorhexidine gluconate solution and sodium hypochlorite solution as root canal irrigants. J Endod 1982;8:200-204.

10. Siqueira JF, Batista MD, Fraga RC, Uzeda M. Antimicrobial effects of endodontic irrigants on black-pigmented Gram-negative anaerobes and facultative bacteria. J Endod 1998;24:414416.

11. Estrela C, Estrela CRA, Barbin EL, Spanó JC, Marchesan MA, Pécora JD. Mechanism of action of sodium hypochlorite. Brazil Dent J 2002;2:113-117.

12. Spangberg L, Engstrom B, Langeland K. Biological effect of dental materials: 3 toxicity and antimicrobial effects of endodontic antiseptics in vitro. Oral Surg Oral Med Oral Pathol 1973;36:856-871.

13. Holland R, Soares IJ, Soares IM. Influence of irrigation and 
intracanal dressing on the healing process of dog's teeth with apical periodontitis. Endod Dent Traumatol 1992;8:223-229.

14. Costa CAS. Teste de biocompatibilidade dos materiais odontológicos. In: Metodologia Científica: ensino e pesquisa em odontologia. Estrela C, ed. São Paulo: Artes Médicas, 2001.

15. Estrela C, Ribeiro RG, Estrela CRA, Pécora JD, Sousa-Neto MD. Antimicrobiol effect of $2 \%$ sodium hypochlorite and $2 \%$ chlorhexidine tested by different methods. Braz Dent J 2003; 14: 58-62.

16. Spanó JCE, Barbin EL, Santos TC, Guimarães LF, Pécora JD. Solvent action of sodium hypochlorite on bovine pulp and physico-chemical properties of resulting liquid. Braz Dent $\mathrm{J}$
2001;12:154-157.

17. Emilson CG. Susceptibility of various microorganisms to chlorhexidine. J Dent Res 1977;85:255-265.

18. Emilson CG. Potential efficacy of chlorhexidine against mutans streptococci and human dental caries. J Dent Res 1994;73:682691.

19. Buck RA, Cai J, Eleaser PD, Staat RH, Hurst HE. Detoxification of endotoxin by endodontic irrigants and calcium hydroxide. J Endod 2001;27:325-327.

20. Barbosa SV, Spangberg LSW, Almeida D. Low surface tension of calcium hydroxide solutions in an effective antiseptic. Int Endod J 1994; 27:6-10.

Accepted June 2, 2003 